\section{References}

Grosse, G., Schirrmeister, L. and Malthus, T.J. 2006: Application of Landsat-7 satellite data and a DEM for the quantification of thermokarst-affected terrain types in the periglacial Lena-Anabar coastal lowland, Polar Research, 25: 51-67.

Plug, L.J. and West, J.J., in press: Thaw lake expansion in a twodimensional coupled model of heat transfer, thaw subsidence and mass movement, Journal of Geophysical Research, doi:10.1029/2006JF000740
Romanovskii, N.N., Hubberten, H.-W., Gavrilov, A.V., Tumskoy, V.E., Tipenko, G.S., Grigoriev, M.N. and Siegert, C., 2000: Thermokarst and Land-Ocean Interactions, Laptev Sea Region, Russia, Permafrost and Periglacial Processes, 11: 137-152.

Walter, K.M. Zimov, S.A., Chanton, J.P. Verbyla, D. and Chapin F.S., 2006 Methane bubbling from Siberian thaw lakes as a positive feedback to climate warming, Nature, $443 ;$ : 71-75.
Walter, K.M., Edwards, M.E., Grosse, G., Zimov, S.A. and Chapin F.S.III., 2007b: Thermokarst lakes as a source of atmospheric $\mathrm{CH}_{4}$ during the last deglaciation, Science, 318: 633-636.

For full references please consult:

www.pages-igbp.org/products/newsletters/ref2009_1.htm

\title{
Initial results of HOTRAX address a wide range of Arctic paleoclimate issues
}

\author{
Dennis A. Darby ${ }^{1}$, L. Polyak ${ }^{2}$ and M. Jakobsson ${ }^{3}$
}

'Deptartment of Ocean, Earth and Atmospheric Sciences, Old Dominion University, Norfolk, USA; ddarby@odu.edu

2Byrd Polar Research Center, Ohio State University, Columbus, USA; 'BDeptartment of Geology and Geochemistry, Stockholm University, Sweden

\section{The Healy-Oden Trans-Arctic Expedition (HOTRAX'05) obtained an exceptional collection of sediment cores from across the Arctic Ocean to address the key unresolved issues of Arctic paleoceanography.}

The HOTRAX expedition retrieved 21 jumbo piston cores averaging $\sim 12 \mathrm{~m}$ in length from a complete transect across the Arctic Ocean, in combination with multibeam bathymetric surveys and chirp-sonar subbottom profiling, and 8 cores of up to $16 \mathrm{~m}$ in length from the continental margin off Alaska (Fig. 1). These Alaskan margin cores have extremely high sedimentation rates $(1.5 \mathrm{~m} / \mathrm{kyr})$ that provide unprecedented Holocene paleoceanographic records, while the central Arctic cores provide records that permit comparisons between earlier warm intervals and those of the Holocene. Together with previously collected core material, we are now better able to grasp the complex array of sediment archives in the Arctic Ocean and to address the important issues of past climate change.

The paleoclimate record in the Arctic has been sorely lacking compared to the rest of the World Ocean because of the difficulties in obtaining quality Arctic records. Even with the greatly improved technology, which includes better icebreakers, coring equipment, improved multibeam and chirp profilers critical for locating potential core sites, and, yes, even with the warming climate providing record low ice extent in the last two years, challenges exist that are unique to the Arctic. HOTRAX made significant strides in providing quality records but more will be required in order to overcome the obstacles to a comprehensive Arctic paleoclimate history.

Climate change in the Arctic commands the close attention of the scientific community as average temperatures in the Arctic over the past 30 years have increased at almost twice the rate of the planet as a whole and sea ice is disappearing at alarming rates. Climate models based on these observations suggest that the Arctic is rapidly moving toward a new, low-ice or even seasonally ice-free state that has not been witnessed in human history. In fact, data from long drill cores recovered by the Arctic Coring Expedition (ACEX; Fig. 1) from the Lomonosov Ridge suggest that the Arctic perennial ice cover may have been around for at least $14 \mathrm{Myr}$ (Darby, 2008). Its disappearance would be a truly monumental change, going far beyond human history.

Of course, the core recovery and resolution of sampling in the ACEX drill cores, upon which this is based, are not sufficient to confirm that there were no ice-free periods over this long time interval. Evidence of past reduced ice cover has been documented from coastal Arctic records from the Miocene (Williams et al., 2008), at least part of the Pliocene, and some of the Quaternary Interglacials (e.g., BrighamGrette and Carter, 1992; CAPE members, 2006) and the early Holocene (England et al, in press; Funder and Kjaer, 2007). This highlights the need for higher resolution records in the Arctic Ocean covering as much of the Cenozoic as possible. To understand the range of variability for future Arctic climates, we need to explore paleoclimate archives with a special focus on

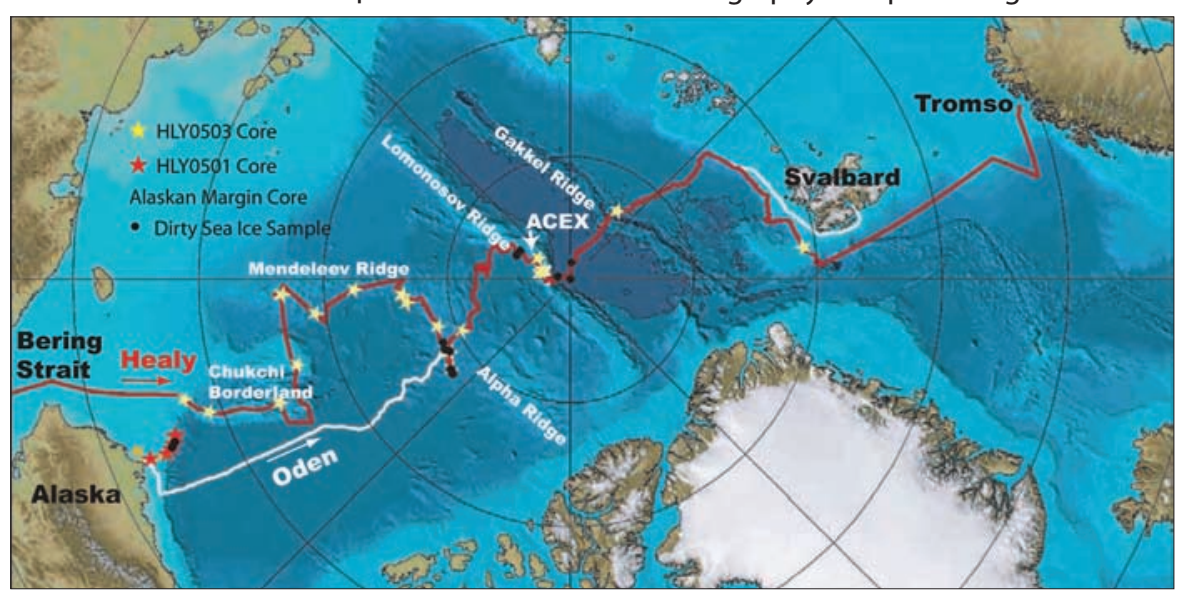

Figure 1: International Bathymetric Chart of the Arctic Ocean (Jakobsson et al., 2008) showing core locations from the Healy-Oden Trans-Arctic Expedition (HOTRAX) in 2005. At each core site, in addition to the 10-cm-diameter piston core and gravity trigger core (2-3 $m$ in length), there is a multicore consisting of 7-8 half-m-long tubes containing the sediment water interface. Black circles indicate the location of several dirty sea-ice samples collected during HOTRAX (used to provide insights on sea ice drift). low-ice periods of the recent geological past. Great strides have been made with the Greenland ice core records (Bond et al., 1993; Calder et al., 2008) but for all the advances they have brought, the Arctic Ocean record of change is still critical because the Greenland records appear to be more closely linked to the North Atlantic than the Arctic, and it is this single ocean that serves as the primary heat sink for the northern hemisphere.

The initial results of work on the HOTRAX cores and other Arctic archives are being prepared for publication in a special issue of Global and Planetary Change (GPC). In another special issue celebrating IPY slated for publication later this year in the Canadian Journal of Earth Science, there are three papers based on HOTRAX cores. Because stratigraphy and age control are the foundation of any paleoclimate history, these special issues have several HOTRAX papers focusing on this topic. A variety of tools are used to determine the age models for these sediment records including AMS radiocarbon dating, ${ }^{210} \mathrm{~Pb},{ }^{10} \mathrm{Be}$, amino-acid racemization rates, luminescence, biostratigraphy and paleomagnetic inten- 


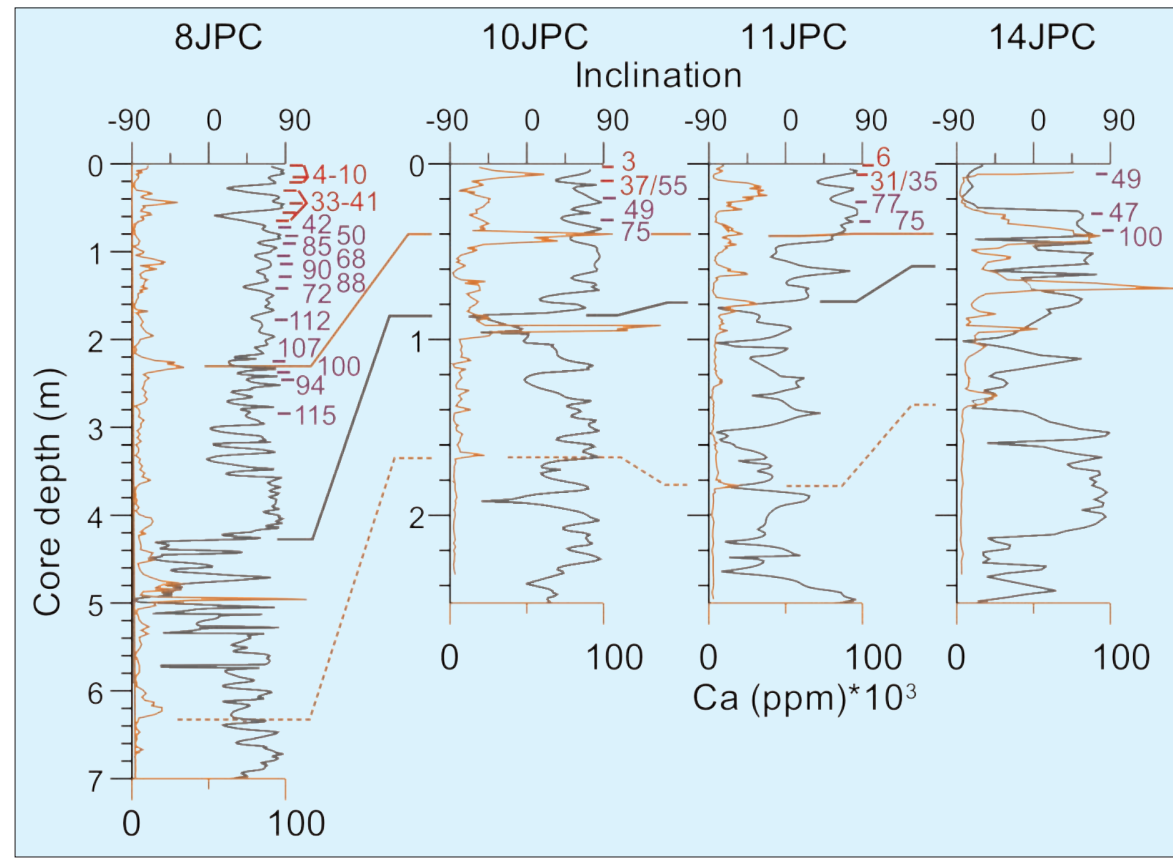

Figure 2: Correlation of paleomagnetic inclination (gray plots) and detrital carbonates (XRF Ca content; orange plots) for upper parts of HOTRAX cores 8, 9, 10 and 14JPC from Mendeleev-Alpha Ridges, south to north (see Fig. 1 for core location) (from Polyak et al., in review). Correlation lines are shown for a prominent carbonate layer at ca. MIS 5/6 boundary (orange), prominent inclination drop within MIS 7 (gray), and base of detrital carbonate deposition (dashed orange). Radiocarbon and amino-acid racemization ages (kyr) are shown in red and purple, respectively. Radiocarbon ages in core HLY0503-8JPC are grouped for simplicity. Note a two-fold change in core depth scale between southern and northern Mendeleev Ridge cores (i.e., between cores 8JPC and 10JPC).

sity fluctuations dated elsewhere from global and regional datasets. These papers also reveal the problems with dating Arctic sediments, in particular dissolution and uncertain reservoir corrections that might even change during the Holocene due to the influence of differing water masses on some slope areas.

Other papers deal with depositional changes in the Holocene and processes responsible for the extremely high sedimentation rates along the Alaskan margin. The important role of sea-ice transport and deposition of sediment in the Arctic is generally accepted but there are still many questions remaining, e.g., just how important sea ice melt-out is to the deposits in various parts of the Arctic. In the GPC HOTRAX issue a number of papers based on cores from the central Arctic Ocean with longer stratigraphy and lower sedimentation rates provide new stratigraphic constraints, especially for the Upper Quaternary, and correlate records between areas with different depositional environments.

Figure 2 exemplifies the correlation of cores along the Mendeleev and Alpha Ridges, based on normal remanent mag- netization (NRM) records, along with distribution of detrital carbonates (indicated by Ca concentrations), and radiocarbon and amino-acid racemization (AAR) dates. Being overall much lower than on the Alaskan margin, sedimentation rates in the central Arctic appear to change dramatically, from nearly a hiatus in some areas during the height of glacial intervals to several $\mathrm{cm} /$ kyr during deglaciations and interglacial intervals. In addition to HOTRAX materials, the GPC special issue presents related data from the Siberian seas and modeling results of the MIS6 glaciation-potentially the biggest ice sheet in the history of the Eurasian Arctic.

\section{Note}

Data from this research is being archived at the Joint Office for Science Support at the University of Colorado. Metadata on the HOTRAX collection are posted on the NGDC MGG website (www.ngdc.noaa.gov/mgg/curator/curator. html).

\section{References}

Bond, G., Broecker, W., Johnsen, S.J., McManus, J., Labeyrie, L., Jouzel, J. and Bonani, G., 1993: Correlations between climate records from North Atlantic sediments and Greenland ice, Nature, 365 143-147.

Calder, C.A., Craigmile, P.F. and Mosley-Thompson, E., 2008: Spatial variation in the influence of the North Atlantic Oscillation on precipitation across Greenland, Journal of Geophysical Research, 113:D06112, doi.1029/2007JD009227

Darby, D.A., 2008: The Arctic perennial ice cover over the last 14 million years, Paleoceanography, 23: PA1507, doi:10.1029/2007PA001479

Jakobsson, M., Macnab, R., Mayer, L., Anderson, R., Edwards, M., Hatzky, J., Schenke, H.W. and Johnson, P., 2008: An improved bathymetric portrayal of the Arctic Ocean: Implications for ocean modeling and geological, geophysical and oceanographic analyses, Geophysical Research Letters, 35: L07602.

Polyak, L., et al., in review: Late Quaternary stratigraphy and sedimentation patterns in the western Arctic Ocean, Global and Planetary Change.

\title{
Lake El'gygytgyn's emerging IPY record of Pliocene to recent Arctic change
}

\author{
Julie Brigham-Grette ${ }^{1}$, M. Melles², P. Minyuk ${ }^{3}$, C. Koeberl ${ }^{4}$ and Science Party \\ 'Department of Geosciences, University of Massachusetts, Amherst, USA; juliebg@geo.umass.edu \\ ${ }^{2}$ Institute of Geology and Mineralogy, University of Cologne, Germany; ${ }^{3}$ North-East Interdisciplinary Scientific Research Institute, Magadan, Rus- \\ sia; ${ }^{4}$ Department of Geological Sciences, University of Vienna, Austria

\section{effort to collect the complete paleoclimate archive from this region back to 3.6 Myr ago.} \\ Lacustrine sediments representing the last 3 glacial cycles from NE Russia chronicle the magnitude and \\ dynamics of millennial-scale change across the western Arctic. Logistics are now underway in a multi-national
}

Imagine looking at a circum-Arctic map of northern hemisphere glacial ice extent and being given the opportunity to select an ideal setting where one might record an undisturbed time-continuous terrestrial record of Arctic climate change. Unprecedented, Lake El'gygytgyn (pronounced el'geegitgin), is such a place, formed by astrophysical chance 3.6 Myr ago, when a meteorite struck Earth $100 \mathrm{~km}$ north of the Arctic Circle in Chukotka on the drainage divide between the Arctic Ocean and the Bering Sea (Layer, 2000) (Fig. 1).

When the meteorite hit, the middle Pliocene Arctic was exceedingly different from today, with mean annual tem- peratures estimated at $12^{\circ} \mathrm{C}$ warmer and global averages $3-4^{\circ} \mathrm{C}$ warmer than today (Dowett, 2007; Saltzman et al., 2008). At that time, most of the Arctic borderlands were heavily forested, the Arctic Ocean lacked permanent sea ice, and the Greenland Ice Sheet did not exist, at least in its present form (Brigham-Grette and Carter, 